\title{
Combustion, Performance and Emissions of a Diesel Power Generator with Direct Injection of B7 and Port Injection of Ethanol
}

\author{
Alex de Oliveira \\ Pontifical Catholic University of Minas Gerais, Department of Mechanical Engineering \\ Av. Dom José Gaspar, 500 - 30535-610 - Belo Horizonte - MG - Brazil \\ Tel.: +55-31-9793-5407 - Fax: +55-31-3319-4910 - E-mail: alexoem@gmail.com
}

\author{
André Marcelino de Morais \\ Pontifical Catholic University of Minas Gerais, Department of Mechanical Engineering \\ Av. Dom José Gaspar, 500 - 30535-610 - Belo Horizonte - MG - Brazil \\ Tel.: +55-31-8788-5626 - Fax: +55-31-3319-4910 - E-mail: andre.mmor@ gmail.com
}

\section{Osmano Souza Valente}

Pontifical Catholic University of Minas Gerais, Department of Mechanical Engineering Av. Dom José Gaspar, 500 - 30535-610 - Belo Horizonte - MG - Brazil Tel.: +55-31-9951-5567 - Fax: +55-31-3319-4910 - E-mail: osmano.valente@ gmail.com

\section{José Ricardo Sodré*}

Pontifical Catholic University of Minas Gerais, Department of Mechanical Engineering Av. Dom José Gaspar, 500 - 30535-610 - Belo Horizonte - MG - Brazil Tel.: +55-31-3319-4911 - Fax: +55-31-3319-4910 - E-mail: ricardo@pucminas.br Birmingham City University, School of Engineering and the Built Environment Millenium Point, Curzon St., Birmingham B4 7XG, UK Tel.: +44 (0)121 2022420 Ext. 7458, E-mail: jose.sodre@bcu.ac.uk

\footnotetext{
${ }^{*}$ Corresponding author
} 


\begin{abstract}
This work investigates a diesel engine operating with diesel oil containing 7\% biodiesel (B7) and hydrous ethanol with concentrations varying from $5 \%$ to $30 \%$. The experiments were conducted in a $49 \mathrm{~kW}$ diesel power generator, equipped with an electronic ethanol injection unit installed in the intake manifold and without any modifications in the diesel oil injection system. The results showed a decrease of in-cylinder pressure and net heat release rate with the use of ethanol at low loads and an increase at high loads, in comparison with B7. Increasing ethanol injection caused increased ignition delay and decreased combustion duration. Fuel conversion efficiency was raised up to $13 \%$ with the use of ethanol. The use of $30 \%$ ethanol in the fuel caused a reduction of carbon dioxide $\left(\mathrm{CO}_{2}\right)$ emissions up to $12 \%$ and nitric oxide (NO) up to 53\%. Carbon monoxide (CO), total hydrocarbons (THC) and oxides of nitrogen $\left(\mathrm{NO}_{\mathrm{x}}\right)$ emissions increased with ethanol addition. The replacement of $20 \%$ of diesel fuel by ethanol showed the lowest penalties on NOx emissions.
\end{abstract}

Keywords: ethanol; diesel engine; combustion; emissions; power generation. 
In recent years, the allowable limits of internal combustion engine pollutant emissions has been reduced as a consequence of increasing concern for the environment and air quality. Ethanol is a renewable fuel that can be obtained from plants such as sugar cane and corn. Several authors highlight ethanol characteristics such as the high latent heat of vaporization, high oxygen content and high burning rate, giving it high potential to reduce oxides of nitrogen $\left(\mathrm{NO}_{\mathrm{X}}\right)$ and particulate matter $(\mathrm{PM})$ emissions from diesel engines [1-3]. Brazil is a major ethanol producer [4] and its main source is sugar cane, which has one of the highest ratio of renewable energy produced to fossil energy used in the production of the fuel.

There are different techniques to use ethanol in diesel engines: blended to diesel oil, fumigated in the intake manifold, dual injection of ethanol and diesel oil, spark ignition conversion and surface ignition [5]. Diesel oil demand can be replaced by up to $50 \%$ using ethanol fumigation, up to $90 \%$ using dual injection and up to $25 \%$ using diesel oil-ethanol blends [6]. Compared with diesel oil, the main limitations of the use of ethanol in diesel engines are the ethanol higher auto ignition temperature, the lower cetane number, which difficult the compression ignition, the lower low heating value (LHV), the lower miscibility of the fuels, mainly with the presence of water, and the lower lubricant properties [7-10].

Bodisco [11] reported that the addition of fuels to the intake air for combustion engines, called indirect injection, has been investigated since the late 1920 s, with the commercialization of the first dualfuel vehicle in 1939. The author points out that methanol and ethanol are suitable for use as secondary fuel. Ethanol fumigation in the intake manifold is a technique of dual fuel engine operation, where ethanol is mixed with the intake air while diesel fuel is injected directly into the combustion chamber as the pilot fuel. This method requires little engine modifications and ethanol is injected into the intake manifold by lowpressure nozzles $[12,13]$. The high compression ratio of diesel engines is an advantage when exploring the high resistance to detonation of ethanol [14].

Padala et al. [14] conducted experiments in an automotive single engine diesel engine using ethanol fumigation. Diesel fuel was injected directly into the combustion chamber and an ethanol injector was installed in the intake manifold with electronically controlled time and duration of injection. Tests were carried out varying the ethanol content up to $70 \%$, compared to diesel oil, based on the energy required for each demanded engine load. The results showed an increase in the ignition delay with the ethanol addition, reduction of $\mathrm{CO}$ emissions and increase in emissions of $\mathrm{NO}_{\mathrm{X}}$ and $\mathrm{THC}$. 
Zhang et al. [15] conducted experiments in a four-cylinder diesel engine with direct injection of diesel oil and rated power of $88 \mathrm{~kW}$. An electronic control unit was developed for controlling the injection of ethanol in the intake manifold. The replacement percentages used, in energy basis, were $10 \%$ and $20 \%$ ethanol. The results showed an increase in fuel consumption, with ethanol fumigation, and reduction of fuel conversion efficiency at low loads and increase at higher loads, when compared with diesel oil performance. Regarding emissions, the authors reported an increase of total hydrocarbons (THC) and carbon monoxide (CO) emissions, as higher percentages of ethanol were used, mainly at low loads. NOx emissions were reduced, attributed to ethanol cooling effect, but carbon dioxide $\left(\mathrm{CO}_{2}\right)$ emission increased.

Tutak [16] presented experimental results using E85 (85\% ethanol and 15\% gasoline) fumigation in a diesel engine, replacing up to $90 \%$ diesel oil by E85. For replacement levels above 50\%, the engine presented combustion problems. The results showed that E85 fumigation caused lower fuel conversion efficiency at low loads and higher fuel conversion efficiency at high loads. The increase in E85 fumigation increased ignition delay, peak pressure and peak heat release rate. The author evaluated emissions using E85 and found, compared to pure diesel fuel, a reduction in NOx emission at low and medium loads and an increase at full load. The results showed increased CO and THC emissions with increasing percentages of ethanol.

Britto et al. [17] tested a single cylinder diesel engine with compression ratio adjustment with a diesel injector located in the center of the combustion chamber and two ethanol injectors positioned upstream of the cylinder head inlet. The results showed increased CO and THC emissions, attributed to the ethanol cooler effect and non- homogeneous air-ethanol mixture.

This work presents the use of diesel oil containing 7\% of biodiesel (B7) directly injected into the engine combustion chamber and hydrous ethanol injection into the engine intake manifold and its effect on combustion, performance and emissions. Ethanol injection was electronically controlled, with concentrations of $5 \%, 10 \%, 15 \%, 20 \%, 25 \%$ and $30 \%$. The experiments were performed in a $44 \mathrm{~kW}$ diesel power generator.

\section{METHODOLOGY}

\subsection{Experimental Setup}

The main characteristics of the $44 \mathrm{~kW}$ diesel engine used in this study shown by Tab. 1 . The original engine geometry characteristics and the mechanically controlled diesel oil direct injection system 
were not changed for the tests. An electronic injection system was adapted to the engine intake system [18] to control ethanol injection in the dual-fuel operation. The electronic injection system consists mainly of a magnetic sensor and a knock sensor, for engine phase synchronization, and microcontrollers, to control the injection timing, according to engine load demand. A common rail system was developed and adapted to the engine intake manifold for multiport ethanol injection, ensuring that the same amount of fuel is available for each cylinder. The ethanol injectors were positioned $130 \mathrm{~mm}$ from the intake valves. The tests were conducted with fixed injection timing of diesel fuel, at 23 crank angle (CA) degrees before top dead center (BTDC), and ethanol injection at top dead center (TDC), in the beginning of the intake stroke.

Table 1 Diesel engine and generator details

\begin{tabular}{lll}
\hline EQUIPMENT & PARAMETER & TYPE OR VALUE \\
\hline Cycle & Four strokes \\
Diesel oil injection & Direct \\
Bore $\times$ stroke & $102 \mathrm{~mm} \times 120 \mathrm{~mm}$ \\
Number of cylinders & 4, in line \\
& Total displacement & $3.922 \mathrm{~L}$ \\
Intake system & Naturally aspirated \\
Rated power & $44 \mathrm{~kW}$ \\
\hline Number of poles & 4 \\
Voltage & $220 \mathrm{~V}$ \\
Number of phases & 3 \\
Rated power & $55 \mathrm{kVA}$ \\
& Frequency & $60 \mathrm{~Hz}$ \\
\hline
\end{tabular}

The intake air mass flow rate was measured through an orifice plate, with maximum uncertainty of $\pm 2.3 \mathrm{~kg} / \mathrm{h}$. The temperatures of ethanol, diesel oil, ambient air, inlet air, orifice plate inlet, exhaust gas and cooling water temperature were monitored using K-type thermocouples. The maximum uncertainty of the measured exhaust gas temperature was $\pm 7^{\circ} \mathrm{C}$; the remaining temperatures were measured with maximum uncertainty of $\pm 2^{\circ} \mathrm{C}$. The inlet air humidity was measured through a thermo-hygrometer with 
uncertainty of $\pm 2.5 \%$, and the ambient pressure was determined through a Torricelli barometer with resolution of $\pm 1.3 \mathrm{kPa}$. Diesel oil and ethanol consumption were measured through platform balances, with resolutions of $5 \mathrm{~g}$ and $1 \mathrm{~g}$, respectively.

The exhaust gas concentration of total unburned hydrocarbons (THC) was measured by a heated flame ionization detector (HFID) analyzer, with resolution of $\pm 1 \mathrm{ppm}$. Oxides of nitrogen $(\mathrm{NO})_{\text {) and nitric }}$ oxide (NO) concentrations were measured by a heated chemiluminescent detector (HCLD) analyzer, with resolution of $\pm 1 \mathrm{ppm}$. Carbon monoxide $(\mathrm{CO})$ and carbon dioxide $\left(\mathrm{CO}_{2}\right)$ concentrations were determined by non-dispersive infrared (NDIR) analyzers, with resolutions of $\pm 1 \mathrm{ppm}$ and $\pm 0.01 \%$, respectively. Incylinder pressure was measured by a piezoelectric pressure transducer with resolution of $\pm 0.5 \%$. A trigger wheel with a magnetic sensor was used to synchronize the pressure data with the engine cycle. The system was set to obtain the pressure data at 0.1 crank angle intervals. Figure 1 shows a schematic draw of the measurement system. The total uncertainty of the results presented is a combination of both the statistical spread and the instrument uncertainty.

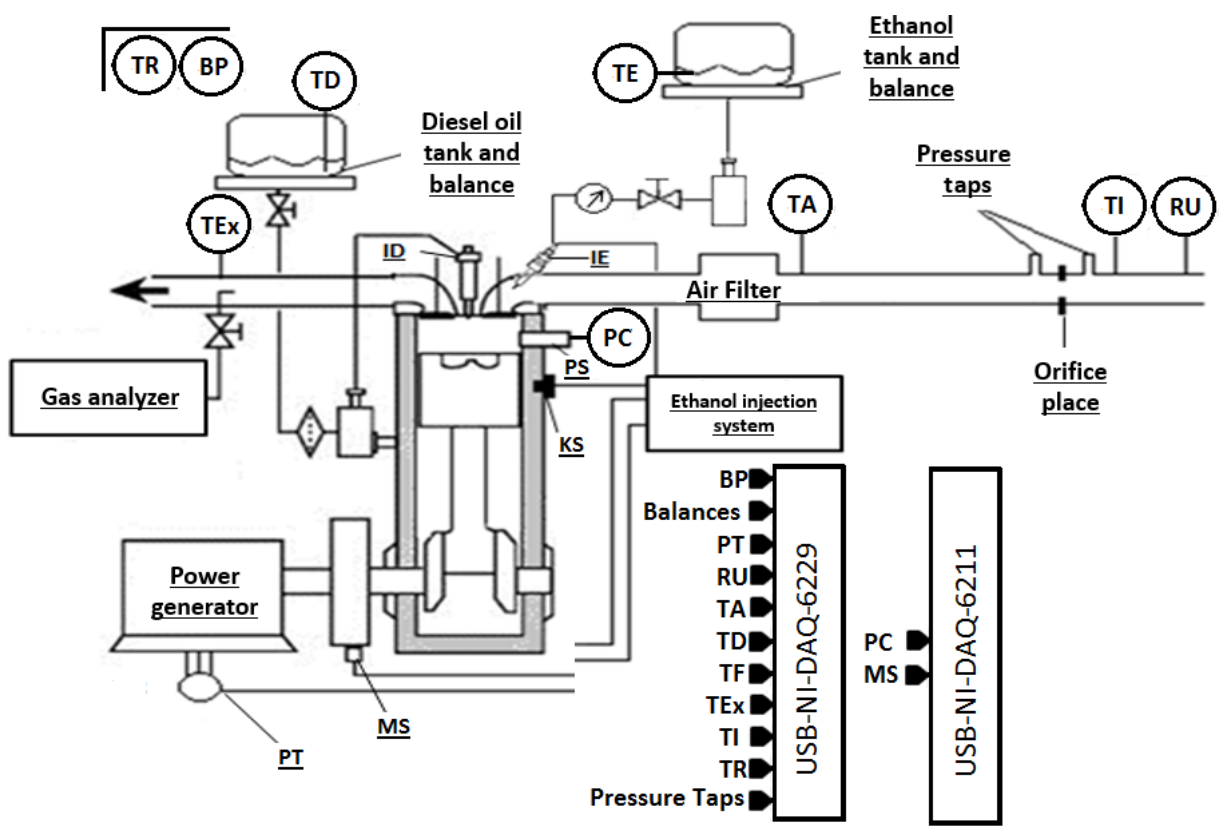

\begin{tabular}{|l|l|}
\hline BP - Barometric pressure & RU - Relative humidity \\
ID - Diesel injector & TA - Intake air temperature \\
IE - Ethanol injector & TD - Diesel oil temperature \\
KS - Knock sensor & TE - Ethanol Temperature \\
MS - Magnetic sensor & TEx - Exhaust temperature \\
PC - In-cylinder pressure & TI - Inlet air temperature \\
PT - Power transducer & TR - Room temperature \\
\hline
\end{tabular}

Fig 1 Schematics of the experimental apparatus 


\subsection{Experimental procedure}

The fuels used during the tests were diesel oil containing 7\% of biodiesel (B7) and hydrous ethanol (92.6\% purity). The replacement percentages used were 0\% (B7E0), 5\% (B7E5), 10\% (B7E10), 15\% (B7E15), 20\% (B7E20), 25\% (B7E25) and 30\% (B7E30). The tests were conducted at the constant engine speed of $1800 \mathrm{rev} / \mathrm{min}$. The loads were varied from $0 \mathrm{~kW}$ to $37.5 \mathrm{~kW}$ and the readings at each load were performed after the engine reached the steady state condition, observing the exhaust gas and the cooling water temperatures. The tests were conducted according to ISO 3046-1:2002 standard [20], which shows the correction of the load power and fuel consumption results to standard conditions.

To set the ethanol injection system, the injected ethanol mass was initially estimated considering the same fuel conversion efficiency for standard operation with diesel oil (B7). Thus, the energy contained in a percentage of B7 mass amount consumed at a specific operating condition in the original engine configuration can be provided by a replacement mass amount of ethanol according to [19]:

$$
m_{E}=P_{\%} \cdot \frac{m_{B 7} \cdot Q_{L H V, B 7}}{Q}
$$

where $m_{E}$ is the ethanol mass flow rate $(\mathrm{kg} / \mathrm{h}), \mathrm{m}_{\mathrm{B} 7}$ is B7 mass flow rate $(\mathrm{kg} / \mathrm{h}), \mathrm{QLHV}, \mathrm{B} 7$ is the low heating value of B7 (MJ/kg), QLHV,E is the low heating value of ethanol (MJ/kg) and $P_{\%}$ is the percentage of ethanol replacement.

The energy content of both fuels, B7 and ethanol, were considered for calculation of the fuel conversion efficiency in dual fuel operation $[15,16]$ :

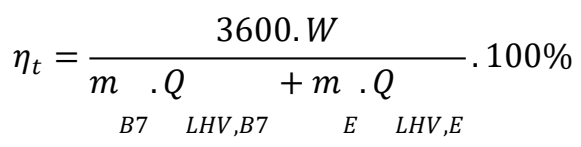

where $\eta_{t}$ is the engine brake fuel conversion efficiency (\%) and W is the engine output power $(\mathrm{kW})$.

The concentration of the exhaust gas component is measured in $\%$ or ppm. To convert molar concentration into specific mass concentration per unit of energy produced, in $\mathrm{g} / \mathrm{kW} . \mathrm{h}$, the following expression is used: 


$$
{ }_{c, g / k w . h}={ }_{c, p p m o r} \% \cdot\left(m_{\text {air }}+m_{B 7}+m_{E}\right) \cdot{\stackrel{\rho_{c}}{\rho} \cdot \frac{1}{W}}_{\text {ex }}
$$

where $C_{, g / k w . h}$ is the component specific composition $(\mathrm{g} / \mathrm{kW} . \mathrm{h}), C_{, p p m \text { or } \%}$ is the component composition $\left(\mathrm{ppm} \times 10^{-6}\right.$ or $\left.\% \times 10^{-2}\right), m_{a r}$ is the intake air mass flow rate $(\mathrm{kg} / \mathrm{h}), \rho_{C}$ is the gas component density $\left(\mathrm{kg} / \mathrm{m}^{3}\right)$ and $\rho_{e x}$ is the exhaust gas density $\left(\mathrm{kg} / \mathrm{m}^{3}\right)$.

The in-cylinder pressure data was used to determine the ignition delay, the combustion duration and the net heat release rate. The ignition delay is determined from the time interval between the start of injection and the start of combustion [21]. The start of combustion was determined from the second order derivative of the in-cylinder pressure diagram [22]. Combustion duration was determined as the crank angle interval between the beginning of heat release and the crank angle where there is an accumulation of $95 \%$ of the total amount of heat released $[6,23]$. The heat release analysis was made for provide the effects of the ethanol on combustion characteristics. The apparent net heat release rate was calculated from application of the first law of Thermodynamics [21]:

$$
\frac{d Q_{n}}{d \theta}=\left(\frac{\gamma}{\gamma-1}\right) \cdot p \cdot \frac{d V}{d \theta}+\left(\frac{1}{\gamma-1}\right) \cdot V \cdot \frac{d P}{d \theta}
$$

where $d Q_{n} / d \theta$ is the apparent net heat release rate $\left(\mathrm{J} /{ }^{\circ} \mathrm{CA}\right), \gamma$ is the ratio of specific heats, $\mathrm{c}_{\mathrm{p}} / \mathrm{c}_{\mathrm{v}}, p$ is the cylinder pressure $(\mathrm{Pa}), \theta$ is the crank angle $\left({ }^{\circ} \mathrm{CA}\right)$ and $\mathrm{V}$ is the cylinder gas volume $\left(\mathrm{m}^{3}\right)$.

\section{RESULTS AND DISCUSSION}

Figures 2 and 3 show the in-cylinder pressure history and the net heat release rate curves as a function of crank angle and the amount of ethanol injected into the engine intake manifold for the loads of $0 \mathrm{~kW}$ and $37.5 \mathrm{~kW}$, respectively. The curves follow the same trend but with a shift of the peak pressure with increasing amount of ethanol due to increased ignition delay. At low loads, the lower temperature of the cylinder gas and the longer ignition delay lead to a peak heat released displaced from the TDC, causing decreased peak pressure. 
At the load of $0 \mathrm{~kW}$, the peak cylinder pressure is generally reduced with increased ethanol content in the fuel (Fig. 2). The peak heat release rate peaks does not show a particular trend with ethanol content in the fuel. Despite the larger amount of accumulated fuel during the ignition delay, the concentrations above $5 \%$ of ethanol did not show significant increase of peak heat release rate. This can be explained by a poor combustion due to the higher cooling effect caused by ethanol, dominant at low loads, causing also reduced peak pressure.

At high loads, the ethanol-diesel oil-air mixture is richer and more fuel is burned during the premixed combustion phase (Fig. 2). In addition, the cylinder gas temperature is higher and the ignition delay is shorter. This behavior causes an increase in peak pressure and heat released. With increasing engine load, the effect of higher amount of air-fuel mixture formed during the ignition delay and burned in the premixed phase is more evident, being dominant for pressure increase with the increase of ethanol concentration [25].

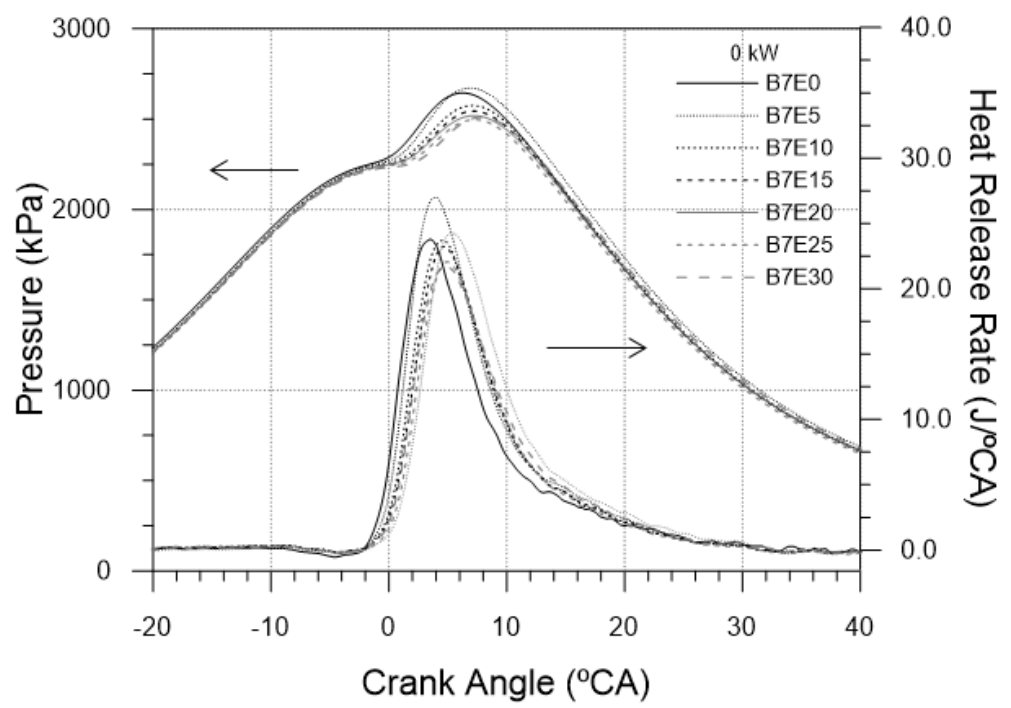

Fig 2 In-cylinder pressure and heat release rate at $0 \mathrm{~kW}$

Figure 3 shows the results of in-cylinder pressure and heat released for the load of $37.5 \mathrm{~kW}$. There is an increase in peak pressure with increasing ethanol content in the fuel. At this load, the difference in the net heat release rate between different ethanol concentrations is amplified, with an increase in the magnitude of the peak pressure and displacement form TDC. This is caused by the fuel accumulated during the ignition delay and the faster burning of ethanol [13]. Several authors have found similar behaviors of in-cylinder 
pressure $[1,6,13]$. The increase in heat release can increase local temperatures of the cylinder structure, requiring the evaluation of the engine cooling system efficiency.

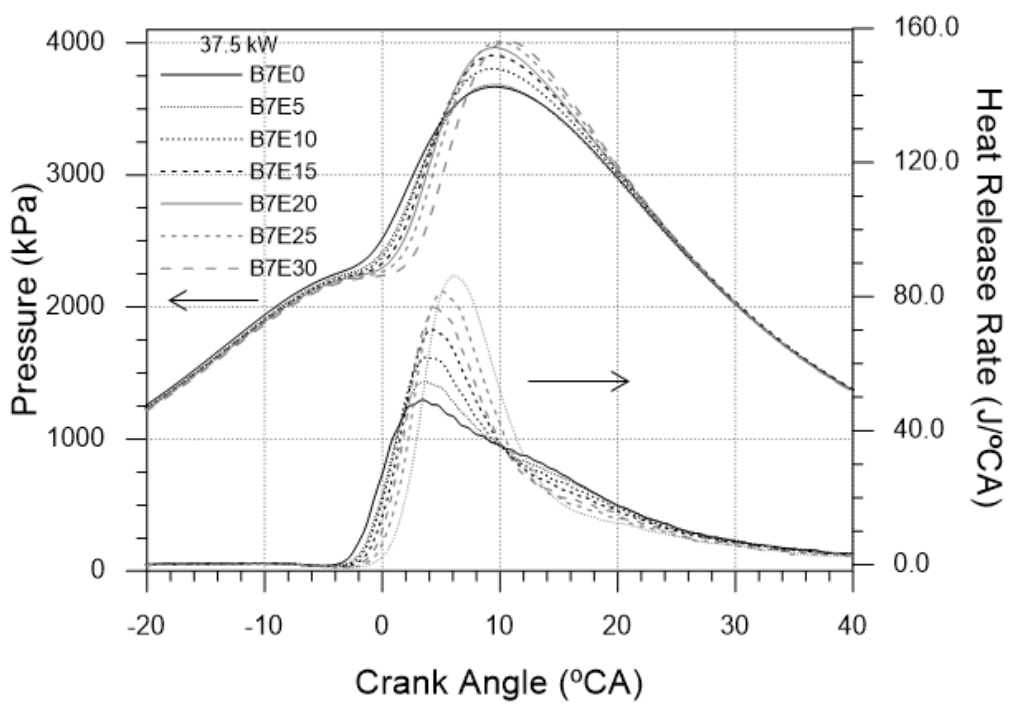

Fig 3 In-cylinder pressure and heat release rate at $37.5 \mathrm{~kW}$

Figure 4 shows increased ignition delay with increasing amount of injected ethanol. The high latent heat of vaporization of ethanol decreases in-cylinder gas temperature, thus reducing the cetane number of the ethanol-diesel oil mixture and, as a consequence, increasing the ignition delay $[6,13,14,16,24]$. Furthermore, when B7 is injected in the cylinder it is not taken by air only, but by an ethanol-air mixture with lower oxygen concentration when compared with pure air, thus increasing the ignition delay. The incylinder gas dilution is increased with increasing ethanol injection $[14,16]$. The results also shows that engine load influences ignition delay, since it is dependent on the cylinder gas temperature and pressure conditions [21]. For B7E0 operation the ignition delay decreased at high loads, due to high in-cylinder temperature. For ethanol operation, at low loads, the in-cylinder temperature is low and the cooling effect of ethanol fumigation is dominant. At high loads and high ethanol concentration, the gas dilution effect and the low cetane number of ethanol increase the ignition delay. The shortest ignition delay, $21.7^{\circ} \mathrm{CA}$, was verified for $\mathrm{B} 7 \mathrm{E} 0$ fuel at $37.5 \mathrm{~kW}$, and the longest ignition delay, $26.2^{\circ} \mathrm{CA}$, occurred to $\mathrm{B} 7 \mathrm{E} 30$ at the same load. 


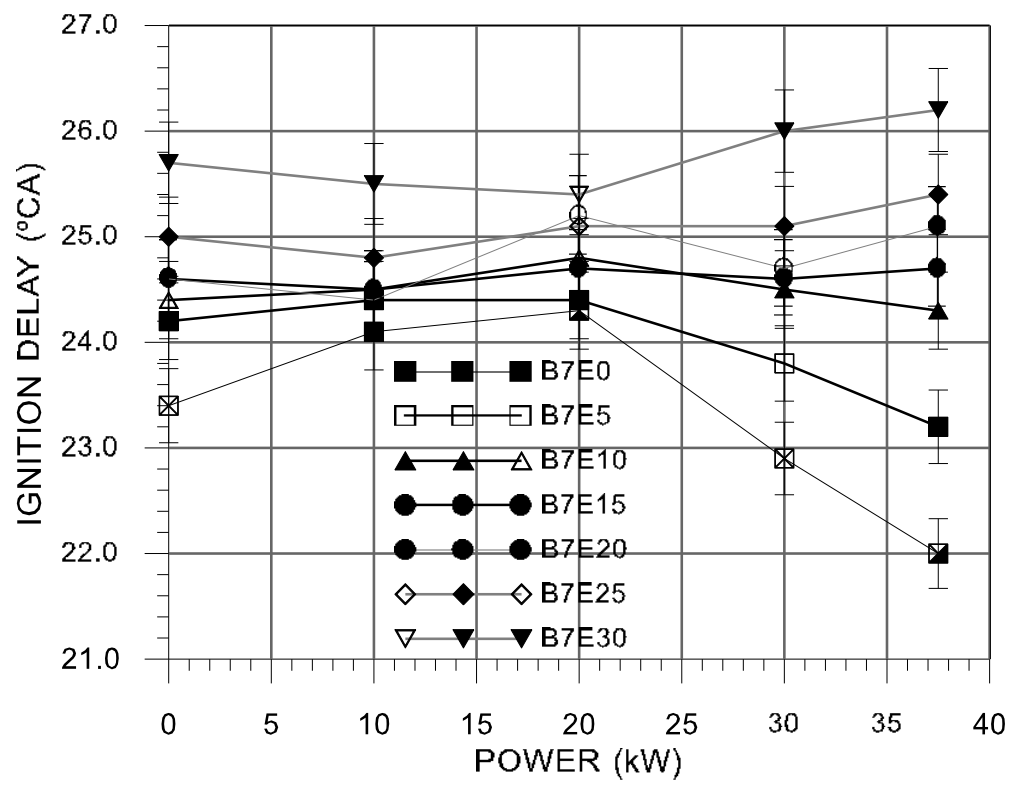

Fig 4 Variation of ignition delay with ethanol concentration and load power

Figure 5 shows the combustion duration as a function of engine load and fuel. Increasing ethanol concentration decreased the combustion duration, justified by the higher heat release rate in the premixed combustion phase caused by the addition of ethanol in the air and increased ignition delay. The addition of ethanol increases the amount of oxygen in the mixture, which reduces the pyrolysis process and increases oxidation during combustion, reducing the combustion duration [23].

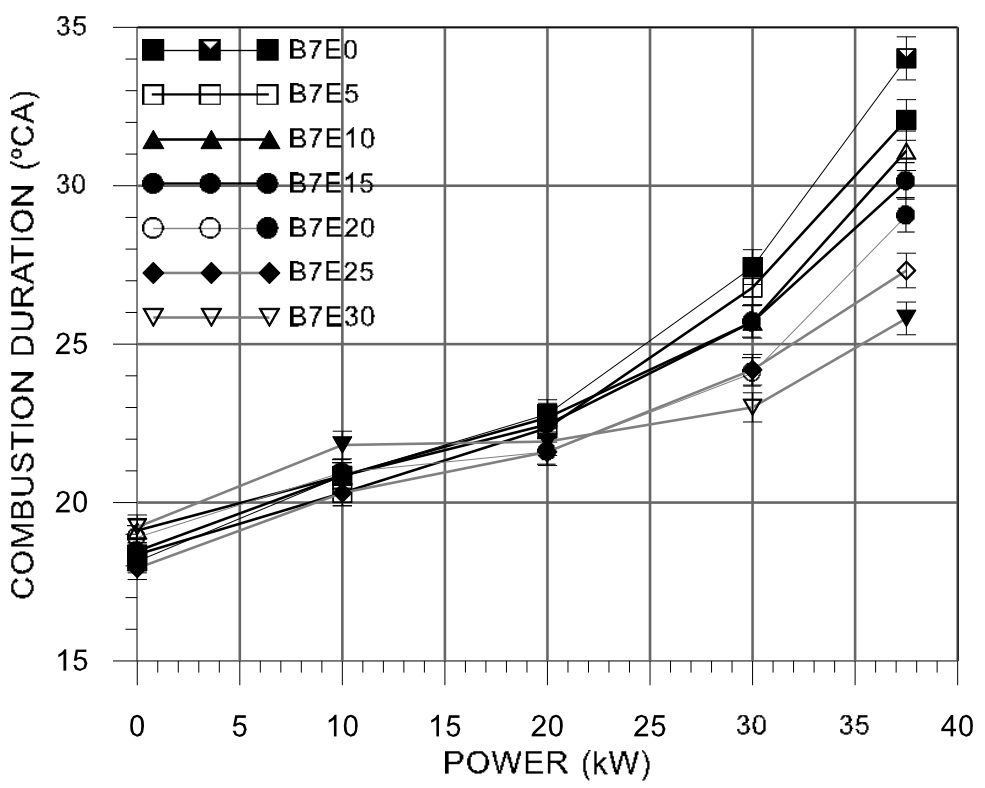

Fig 5 Variation of combustion duration with ethanol concentration and load power 


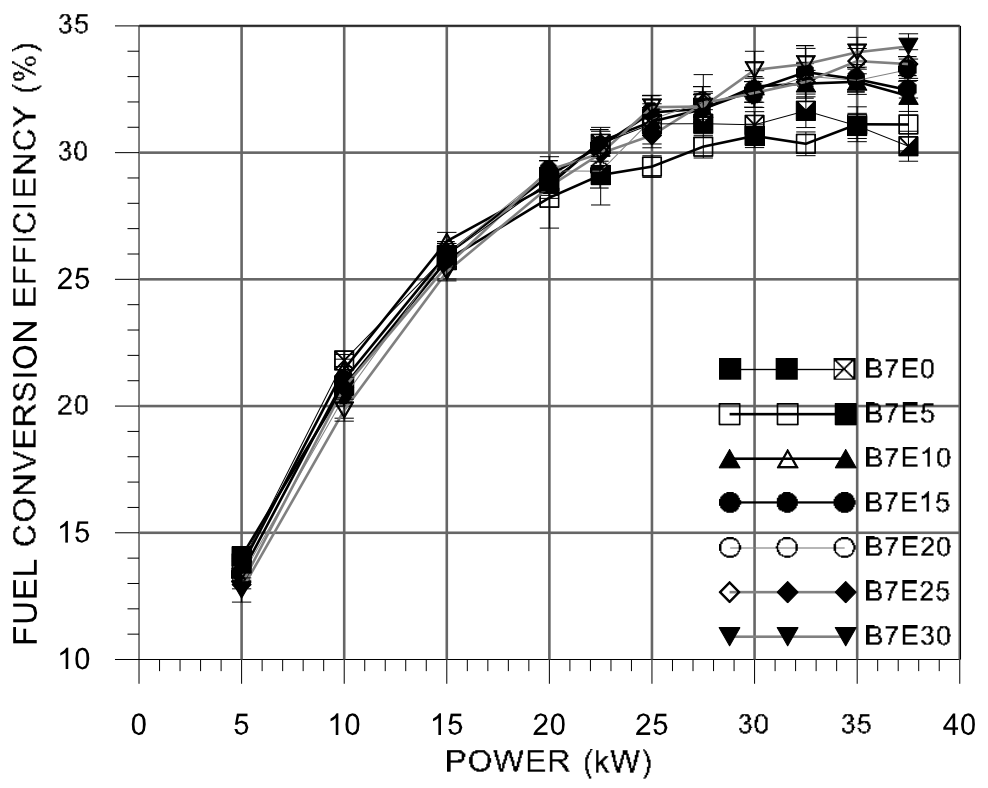

Fig 6 Variation of fuel conversion efficiency with ethanol concentration and load power

In general, there was a reduction of fuel conversion efficiency at low loads and increase at high loads (Fig. 6). At low loads the cooling effects of ethanol vaporization are dominant, decreasing the incylinder gas temperature. Besides, the low amount of ethanol injected form an air/fuel mixture that can be too lean to allow combustion to proceed, resulting in reduced fuel conversion efficiency [16]. At high loads, the larger quantity of fuel burned increases the cylinder gas temperature. These effects, together with the faster burning of ethanol and increased amount of fuel burned in the premixed phase of combustion, in 
comparison with B7, are determinant to decrease or increase the fuel conversion efficiency $[1,13,26,27]$. In addition, at low loads, the reduction of the peak pressure and heat release rate could have contributed to reduce the fuel conversion efficiency. At high loads, there was an increase of these two parameters, having, therefore, increasing fuel conversion efficiency. The largest reduction occurred for B7E20 at the load of 10 $\mathrm{kW}$, when the fuel conversion efficiency was $6.6 \%$ lower than operation with B7E0, and the largest increase was $13.0 \%$, found for operation with B7E30 at the load $37.5 \mathrm{~kW}$.

Figure 7 shows the behavior of the specific $\mathrm{CO}_{2}$ emission for the different ethanol concentrations and loads. As the load was increased, $\mathrm{CO}_{2}$ emission was reduced for all ethanol concentrations. At a given load, in general, increasing ethanol concentration in the fuel also caused a reduction of $\mathrm{CO}_{2}$ emission. The reductions obtained for $\mathrm{CO}_{2}$ emissions were up to $12.2 \%$, for $\mathrm{B} 7 \mathrm{E} 25$. The decrease of cylinder gas temperature due to the high ethanol latent heat of evaporation inhibits $\mathrm{CO}$ oxidation, which leads to a reduction of $\mathrm{CO}_{2}$ emission [14,15]. The presence of oxygen and a single carbon bond in ethanol molecule increases fuel conversion efficiency (Fig. 6), helping to reduce $\mathrm{CO}_{2}$ production (Fig. 7).

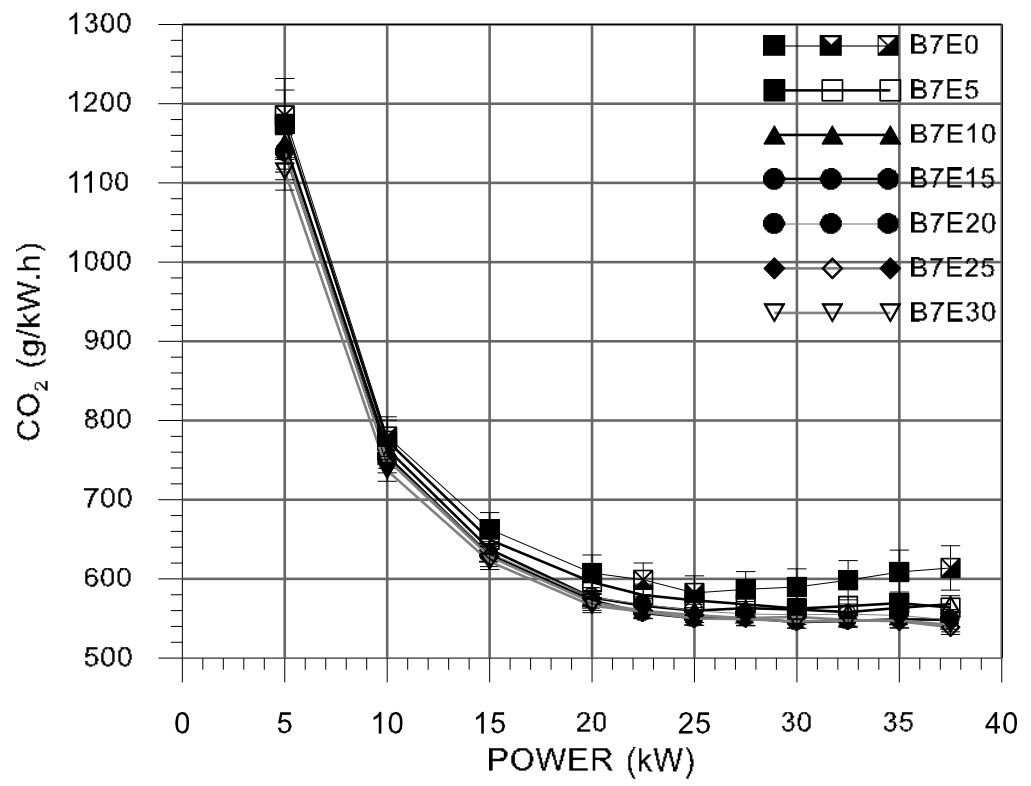

Fig 7 Variation of specific carbon dioxide emissions with ethanol concentration and load power

Figure 8 shows that $\mathrm{CO}$ specific emissions was increased with ethanol concentration in the fuel for all engine loads tested. Zhang et al. [15] explain that $\mathrm{CO}$ emission tend to increase in situations where there is incomplete combustion, under low temperatures and very lean mixtures, and is controlled by the 
local equivalence ratio, being an indicative of combustion quality. $\mathrm{CO}$ oxidation occurs at high combustion temperatures. At low loads, the addition of ethanol leads to a reduction of cylinder gas temperature, resulting in quality loss and lower combustion oxidation of $\mathrm{CO}$ to $\mathrm{CO}_{2}$ in the expansion stroke, increasing the $\mathrm{CO}$ emission $[12,15]$. With the addition of ethanol, there is a reduction of excess air in the cylinder, which has a strong influence to increase $\mathrm{CO}$ emission [3]. At high loads, the effect of ethanol vaporization to decrease cylinder gas temperature is reduced, due to the higher combustion temperatures attained, thus reducing the differences of $\mathrm{CO}$ emissions between the ethanol blends and $\mathrm{B} 7$.

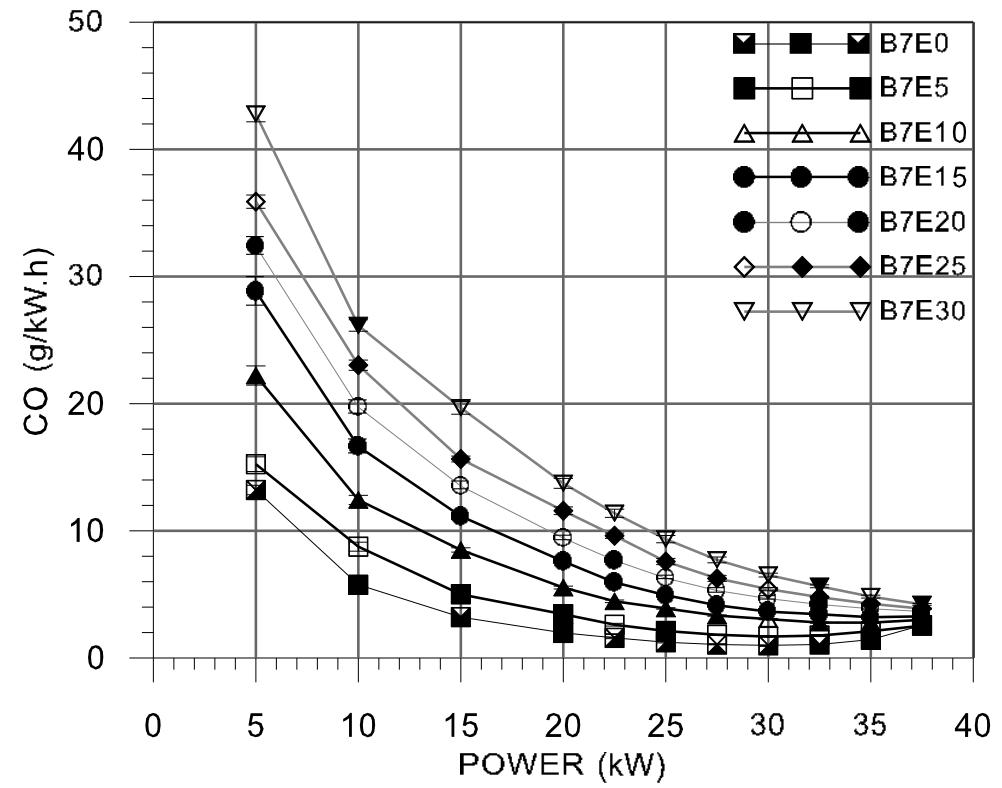

Fig 8 Variation of specific carbon monoxide emissions with ethanol concentration and load power

Figure 9 shows the specific THC emission for the different ethanol concentrations. As it occurred for $\mathrm{CO}$ emissions, THC emission increased with the addition of ethanol. Unburned hydrocarbon formation is strongly dependent on combustion quality; thus, the results indicate the use of ethanol provokes poor combustion. Several factors may have caused the increase of THC emission, such as temperature reduction due to ethanol injection, which causes lower rates of vaporization and mixture formation. For Chauhan et al. [9], at low loads, the indirectly injected ethanol is unable to impinge on surfaces and be distributed, causing poor fuel distribution, large amounts of excess air, low exhaust temperature and lean air-fuel mixtures tend to escape, resulting in higher unburned fuel. The air-ethanol mixture trapped in cylinder crevices during the compression and combustion processes, under increasing cylinder pressure, returns to 
the cylinder during the expansion and exhaust strokes, under decreasing cylinder pressure, and partially undergoes a post-flame oxidation process. The unburned amount escape though the exhaust valve and contribute to the increase of hydrocarbon emissions, a characteristic phenomenon of port fuel spark ignition engines [13,27]. At high loads, the temperature increase allows more burning of the air-fuel mixture, improves the quality of combustion and reduces the increase of hydrocarbon emission [13]. Several researchers, such as Surawski et al. [3], Chauhan et al. [9], Tutak [16] and Yao et al. [27], also report the increase of $\mathrm{CO}$ and THC emissions.

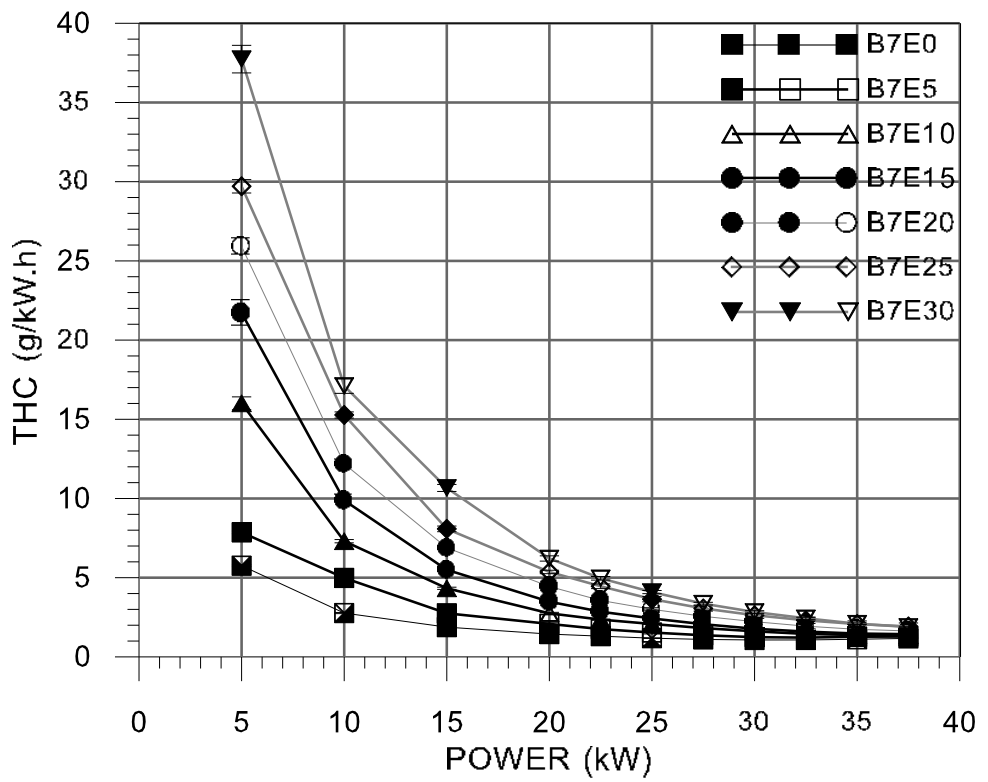

Fig 9 Variation of specific total hydrocarbon emissions with ethanol concentration and load power

Figure 10 shows that NO emission was reduced for all loads when ethanol was used as fuel. The reductions attained were up to 53.2\%, for B7E30. Surawski et al. [3] also found reduction of NO emission for all engine power range with ethanol concentration up to $40 \%$. Several factors affect $\mathrm{NO}_{\mathrm{x}}$ formation and emissions in a diesel engine. The oxygen content and low cetane number of ethanol lead to high temperature peaks and cause increased $\mathrm{NO}_{\mathrm{x}}$, but, on the other hand, the high enthalpy of vaporization and low flame temperature of ethanol lead to decreased $\mathrm{NO}_{\mathrm{x}}$ emissions. The effects of ethanol in $\mathrm{NO}$ emissions are dependent on engine operating conditions and fuel characteristics [28]. Several authors associated reduction of NO emissions to decreased gas temperature caused by ethanol fumigation [15]. This effect is more significant at low loads, since at high loads richer air-fuel mixtures tend to increase combustion temperature. 


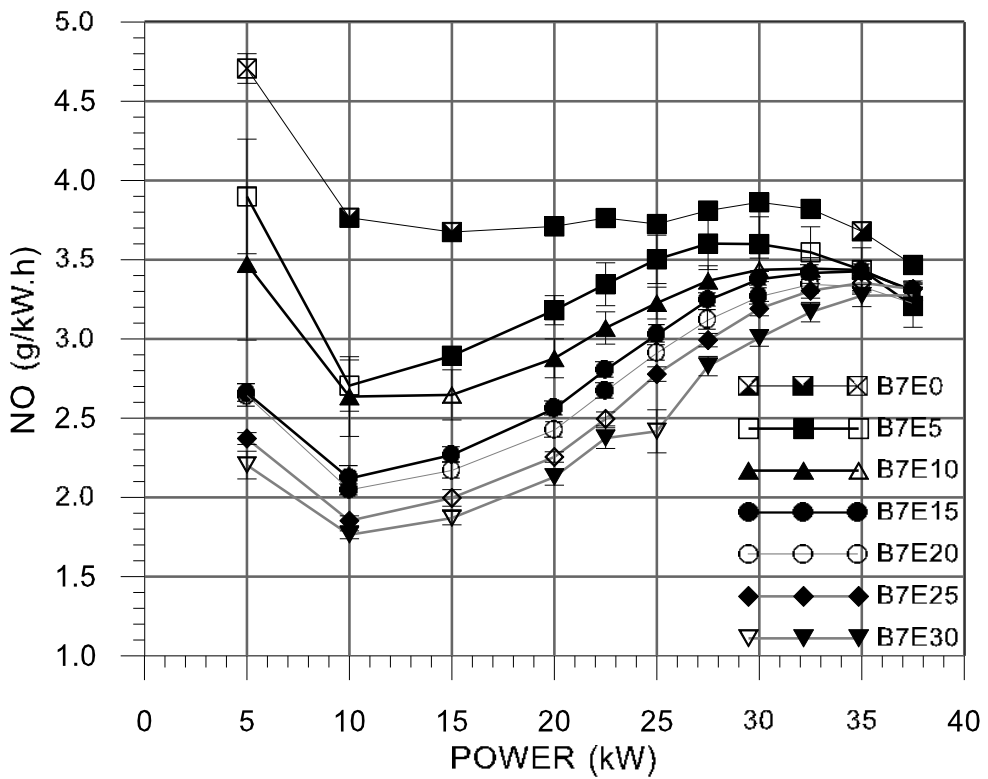

Fig 10 Variation of specific nitric oxide emissions with ethanol concentration and load power

Despite the reduction of NO emission with ethanol fumigation, it was observed an increase of specific NOx emissions for all loads (Fig. 11). The increase in NOx emission is due to the increase of $\mathrm{NO}_{2}$ formation, as Padala et al. [14] and Tutak [16] showed it. This behavior can be caused by the cooling effect of ethanol, as the decrease in temperature favors $\mathrm{NO}_{2}$ formation. Heywood [21] explains that one of nitrogen dioxide formation mechanism is by the combination of NO formed in the flame front with hydroperoxyl radical $\left(\mathrm{HO}_{2}\right)$, also producing hydroxyl $(\mathrm{OH}) . \mathrm{NO}_{2}$ would subsequently combine with oxygen element $(\mathrm{O})$ to form $\mathrm{NO}$ and molecular oxygen $\left(\mathrm{O}_{2}\right)$, unless the $\mathrm{NO}_{2}$ formed in the flame is quenched by mixing with cooler fluid.

Zhu et al. [23] explain that the NO oxidation efficiency depends on the formation of hydroperoxyl radical. The authors cite studies that shows that ethanol could produce $\mathrm{HO}_{2}$ through the thermal degradation behavior of alcohols with $\mathrm{NO}$, and that $\mathrm{HO}_{2}$ is promptly formed during oxidation of oxygenated fuels. Thus, ethanol can be a source of $\mathrm{HO}_{2}$ and increase the oxidation of $\mathrm{NO}$ into $\mathrm{NO}_{2}$, especially at low and medium loads. Furthermore, their results showed significant increases of unburned fuel emission, which favors the formation of $\mathrm{NO}_{2}$ due to the presence of ethanol, a good oxidizing [15], and due to the cold fuel condition, which inhibits the conversion of $\mathrm{NO}_{2}$ to $\mathrm{NO}$ [21]. 
From an analysis of Figs. 10 and 11 for each fuel curve when the engine operated with ethanol, there is tendency of increasing NO emissions for loads below $10 \mathrm{~kW}$ and no single trend is observed for higher loads. From the difference of $\mathrm{NO} x$ and $\mathrm{NO}$ concentrations, it can be inferred that $\mathrm{NO}_{2}$ concentration always increase with decreasing load. At low loads the relatively low temperatures attained in the cylinder do not favor the decomposition of $\mathrm{NO}_{2}$ into $\mathrm{NO}$, while, as the load and combustion product gas is increased, a larger amount of $\mathrm{NO}_{2}$ is decomposed into $\mathrm{NO}$.

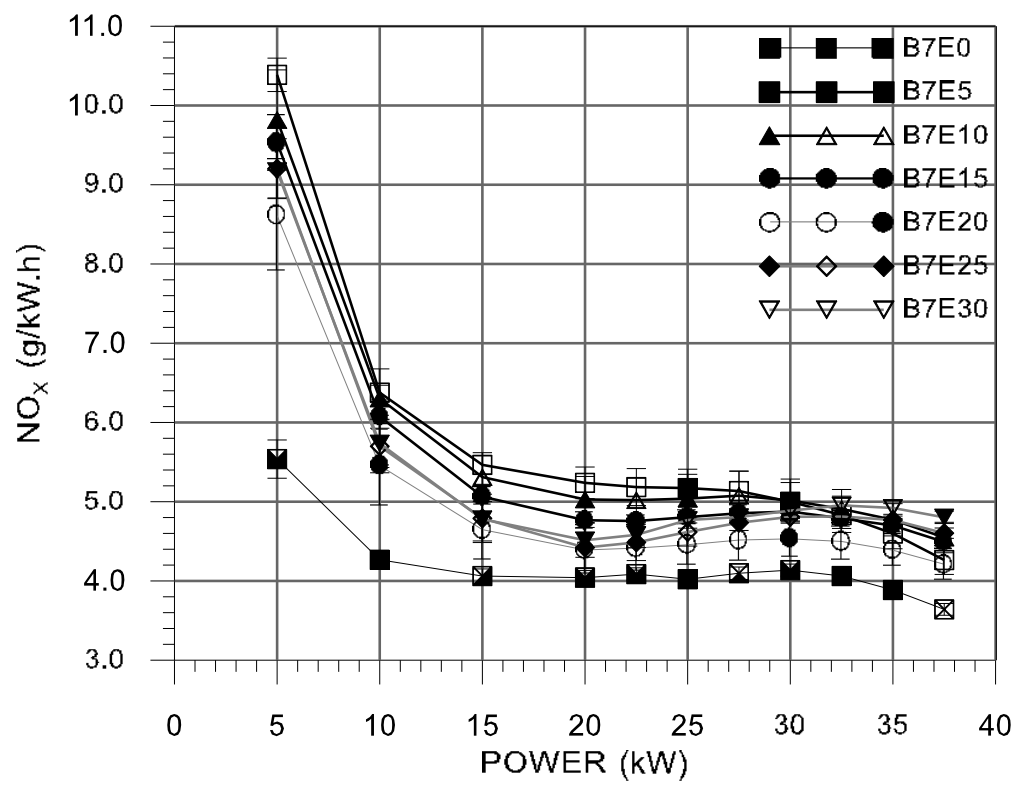

Fig 11 Variation of specific oxides of nitrogen emissions with ethanol concentration and load power

The studied diesel engine does not have any exhaust gas aftertreatment technology. Thus, when operating with diesel oil only, the engine does not meet the current Brazilian emissions standards for diesel engines, PROCONVE (Air Pollution Control Program for Motor Vehicles) P7, based on Euro V European standards for heavy-duty engines, which requires systems as exhaust gas recirculation (EGR) or selective catalytic reduction (SCR). Ethanol addition to $\mathrm{B} 7$ increased $\mathrm{CO}_{2}$, THC and $\mathrm{NOx}$ emissions, however aftertreatments systems could lead to a reduction in these emissions. SCR system is a well-stablished technique to achieve very low levels of $\mathrm{NO}_{\mathrm{x}}$ [29-31]. Tadano et al. [29] showed reductions up to $93 \%$ in NOx using SCR systems in a diesel engine. EGR systems are also very effective in reducing NOx emissions [32-33], but increases smoke emissions, which can be reduced by ethanol addition to the fuel [33-35].

Another extensive used aftertreatment system is diesel oxidation catalyst (DOC), used to oxidize THC and $\mathrm{CO}$ emissions to $\mathrm{H}_{2} \mathrm{O}$ and $\mathrm{CO}_{2}$, respectively, for diesel oil with low sulfur content [36]. This 
system is able to reduces CO and THC emissions to the standards limits [36-42]. Zhang et al. [41] and Wei et al. [42] also showed that alcohol fumigation in diesel engines increased $\mathrm{CO}, \mathrm{NO}_{2}$ and $\mathrm{THC}$ emissions, but, after catalytic conversion, the concentrations of these components were significantly reduced, up to $38 \%$ for THC and $16 \%$ for CO [41], and for levels near diesel fuel operation with DOC system [42]. For diesel fuel operation, Wei et al. [42] showed reductions up to $90 \%$ in CO and THC emissions for high loads.

\section{CONCLUSIONS}

Ethanol was added to B7 in a diesel engine by fumigating in the intake manifold and without any change in the original engine geometry characteristics and in the mechanically controlled diesel oil direct injection system. Ethanol addition increased ignition delay and reduced combustion duration. Peak cylinder pressure and heat release rate were reduced at low loads and increased at high loads. The fuel conversion efficiency was reduced at low loads up to $6.6 \%$, using $20 \%$ ethanol in the fuel, and increased up to $13.0 \%$ at high loads, for $30 \%$ ethanol. $\mathrm{CO}_{2}$ and $\mathrm{NO}$ emissions were reduced in all engine load range tested, reaching up to $12 \% \mathrm{CO}_{2}$ reduction and $53 \% \mathrm{NO}$ reduction with $30 \%$ ethanol concentration in the fuel. $\mathrm{CO}$, THC and NOx emissions always increased with the use of ethanol. The partial substitution of $20 \%$ of diesel fuel by ethanol fumigation at moderate to high loads in an engine with unmodified diesel injection settings is recommended for the lowest penalties on NOx emissions. In general, ethanol fumigation in a stationary diesel engine may require optimization of diesel injection and/or exhaust gas aftertreatment to meet emissions standards. 


\section{ACKNOWLEDGMENTS}

The authors thank the Coordination for the Improvement of Higher Education Personnel (CAPES), the National Counsel of Technological and Scientific Development (CNPq) research project number 304114/2013-8, the Foundation of Support Research of the State of Minas Gerais (FAPEMIG) research projects number TEC PPM 00136-13 and TEC PPM 0385-15, and VALE/FAPEMIG research project number TEC RDP 00198-10 for the financial support to this work.

\section{REFERENCES}

[1] Zhu L, Cheung CS, Zhang WG, Huang Z (2010) Emissions characteristics of a diesel engine operating on biodiesel and biodiesel blended with ethanol and methanol, Sci. Tot. Environ. 408:914-921. doi: 10.1016/j.scitotenv.2009.10.078

[2] Brito RF, Martins CA (2014) Experimental analysis of a diesel engine operating in Diesel-Ethanol Dual-Fuel mode, Fuel 134:140-150. doi: 10.1016/j.fuel.2014.05.010

[3] Surawski NC, Ristovski ZD, Brown RJ, Situ R (2012) Gaseous and particle emissions from an ethanol fumigated compression ignition engine, Energy Convers. Manag. 54:145-151. doi: 10.1016/j.enconman.2011.10.011

[4] Franco ALC, Cherubin MR, Cerri CC, Pavinato PS, Cerri CEP, Six J, Davies CA (2015) Soil carbon, nitrogen and phosphorus changes under sugarcane expansion in Brazil, Sci. Tot. Environ. 515-516:3038. doi: 10.1016/j.scitotenv.2015.02.025

[5] Boretti A (2012) Advantages of converting Diesel engines to run as dual fuel ethanol-Diesel, Appl. Therm. Eng. 47:1-9. doi: 10.1016/j.applthermaleng.2012.04.037

[6] Zhang ZH, Cheung CS, Yao CD (2013) Influence of fumigation methanol on the combustion and particulate emissions of a diesel engine, Fuel 111:442-448. doi: 10.1016/j.fuel.2013.05.014

[7] Kwanchareon P, Luengnaruemitchai A, Jai-In S (2007) Solubility of a diesel-biodiesel-ethanol blend, its fuel properties, and its emission characteristics from diesel engine, Fuel 86:1053-1061. doi: 10.1016/j.fuel.2006.09.034

[8] Lapuerta M, Armas O, Garcia-Contreras R (2007) Stability of diesel-bioethanol blends for used in diesel engines, Fuel 86:1351-1357. doi:10.1016/j.fuel.2006.11.042 
[9] Chauhan BS, Kumar N, Pal SS, Jun YD (2011) Experimental studies on fumigation of ethanol in a small capacity Diesel engine, Energy 36:1030-1038. doi:10.1016/j.energy.2010.12.005

[10] Sahin Z, Durgun O (2007) Theoretical investigation of effects of light fuel fumigation on diesel engine performance and emissions, Energy Convers. Manag 48:1952-1964. doi: 10.1016/j.enconman.2007.01.027

[11] Bodisco T, Brown RJ (2013) Inter-cycle variability of in-cylinder pressure parameters in an ethanol fumigated common rail diesel engine, Energy 52:55-65. doi:10.1016/j.energy.2012.12.032

[12] He BQ, Shuai SJ, Wang JX, He H (2003) The effect of ethanol blended diesel fuels on emissions from a diesel engine, Atmosph. Environ. 37:4965-4971. doi: 10.1016/j.atmosenv.2003.08.029

[13] Tsang KS, Zhang ZH, Cheung CS, Chan TL (2010) Reducing emissions of a diesel engine using fumigation ethanol and a diesel oxidation catalyst, Energy Fuel 24:6156-6165. doi: $10.1021 / \mathrm{ef} 100899 \mathrm{z}$

[14] Padala S, Woo C, Kook S, Hawkes ER (2013) Ethanol utilization in a diesel engine using dual-fueling technology, Fuel 109:597-607. doi:10.1016/j.fuel.2013.03.049

[15] Zhang ZH, Tsang KS, Cheung CS, Chan TI, Yao CD (2011) Effect of fumigation methanol and ethanol on the gaseous and particulate emissions of a direct-injection diesel engine, Atmos. Environ. 45:2001-2008. doi:10.1016/j.atmosenv.2010.12.019

[16] Tutak W (2014) Bioethanol E85 as a fuel for dual fuel diesel engine, Energy Convers. Manag 86:3948. doi: 10.1016/j.enconman.2014.05.016

[17] Britto Júnior RF, Martins CA (2015) Emissions analysis of a diesel engine operating in diesel-ethanol dual-fuel mode. Fuel 148:191-201, doi: 10.1016/j.fuel.2015.01.008

[18] De Oliveira A, Santos ECM, Botelho GC, Valente OS, Sodré JR (2013) Hydrogen electronic injection system for a diesel power generator, Int. J. Hydrogen Energy 38:1-8. doi: 10.1016/j.ijhydene.2013.04.118

[19] Morais AM, Justino MAM, Valente OS, Hanriot SM, Sodré JR (2013) Hydrogen impacts on performance and $\mathrm{CO}_{2}$ emissions from a diesel power generator, Int. J. Hydrogen Energy 38:68576864. doi: 10.1016/j.ijhydene.2013.03.119

[20] International Organization for Standardization ISO 3046-1 (2002) Reciprocating internal combustion engines - Performance - Part 1: Declarations of power, fuel and lubricating oil consumptions, and test methods - Additional requirements for engines for general use 
[21] Heywood JB (2003) Internal combustion engine fundamental, 2nd ed., McGraw-Hill, Singapore

[22] Katrasnik T, Trenc F, Opresnik SR (2006) A new criterion to determine the start of combustion in diesel engines, Trans. ASME J. Eng. Gas Turbine Power 128:928-933. doi:10.1115/1.2179471

[23] Zhu L, Cheung CS, Zhang WG (2011) Combustion, performance and emission characteristics of a DI diesel engine fueled with ethanol-biodiesel blends, Fuel 90:1743-1750. doi: 10.1016/j.fuel.2011.01.024

[24] Hansdah D, Murugan S (2014) Bioethanol fumigation in a DI diesel engine, Fuel 130:324-333. doi:10.1016/j.fuel.2014.04.047

[25] Zhu L, Cheung CS, Zhang WG, Fang JH, Huang Z (2013) Effects of ethanol-biodiesel blends and diesel oxidation catalyst (DOC) on particulate and unregulated emissions, Fuel 113:690-696. doi:10.1016/j.fuel.2013.06.028

[26] Abu-Qudais M, Haddad O, Qudaisat M (2000) The effect of alcohol fumigation on diesel engine performance and emissions, Energy Convers. Manag. 41:389-399. doi: 10.1016/S01968904(99)00099-0

[27] Yao CD, Zhang ZH, Cheung CS, Xu GL (2010) Experimental study on the effect of gaseous and particulate emission from an ethanol fumigated diesel engine, Sci. China Technol. Sc. 53:3294-3301. doi: 10.1007/s11431-010-3187-1

[28] Armas O, García-Contreras R, Ramos A (2014) Pollutant emissions from New European Driving Cycle with ethanol and butanol diesel blends, Fuel Process. Technol. 122:64-71. doi: 10.1016/j.fuproc.2014.01.023

[29] Tadano YS, Borillo GC, Godoi AFL, Cichon A, Silva TOB, Yamamoto CI, Godoi RHM (2014) Gaseous emissions from a heavy-duty engine equipped with SCR aftertreatment system and fuelled with diesel and biodiesel: Assessment of pollutant dispersion and health risk, Sci Total Environ 500501:64-71. doi:10.1016/j.scitotenv.2014.08.100

[30] Jiang J, Li D (2016) Theoretical analysis and experimental confirmation of exhaust temperature control for diesel vehicle $\mathrm{NO}_{\mathrm{x}}$ emissions reduction, Appl Energ 174: 232-244. doi:10.1016/j.apenergy.2016.04.096

[31] Asad U, Kumar R, Zheng M, Tjong J (2015) Ethanol-fueled low temperature combustion: A pathway to clean and efficient diesel engine cycles, Appl Energ 157:838-850. doi: 10.1016/j.apenergy.2015.01.057 
[32] Palash SM, Masjuki HH, Kalam MA, Masum BM, Sanjid A, Abedin MJ (2013) State of the art of $\mathrm{NO}_{\mathrm{x}}$ mitigation technologies and their effect on the performance and emission characteristics of biodiesel-fueled Compression Ignition engines, Energ Convers Manage 76:400-420. doi: 10.1016/j.enconman.2013.07.059

[33] Divekar PS, Chen X, Tjong J, Zheng M (2016) Energy efficiency impact of EGR on organizing clean combustion in diesel engines, Energ Convers Manage 112:369-381. doi: 10.1016/j.enconman.2016.01.042

[34] Hebbar GS, Bhat AK (2013) Control of $\mathrm{NO}_{\mathrm{x}}$ from a DI Diesel Engine with Hot EGR and Ethanol Fumigation: An Experimental Investigation. Int J Automot Techn 14(3):333-341. doi: $10.1007 / \mathrm{s} 12239-013-0037-8$

[35] Park SH, Youn IM, Lee CS (2010) Influence of two-stage injection and exhaust gas recirculation on the emissions reduction in an ethanol-blended diesel-fueled four-cylinder diesel engine, Fuel Process Technol 91:1753-1760. doi: 10.1016/j.fuproc.2010.07.016

[36] Guo M, Fu Z, Ma D, Ji N, Song C, Liu Q (2015) A short review of treatment methods of marine diesel engine exhaust gases, Procedia Engineering 121:938-943. doi: 10.1016/j.proeng.2015.09.059

[37] Stein HJ (1996) Diesel oxidation catalysts for commercial vehicle engines: strategies on their application for controlling particulate emissions, Appl Catal B 10(1-3):69-82. doi: 10.1016/09263373(96)00024-0

[38] Resitoglu IA, Altinisik K (2015) The pollutant emissions from diesel-engine vehicles and exhaust aftertreatment systems, Clean Techn Environ Policy 17:15-27. doi 10.1007/s10098-014-0793-9

[39] Zervas E (2008) Impact of different configurations of a Diesel oxidation catalyst on the CO and HC tail-pipe emissions of a Euro4 passenger car, Appl Therm Eng 28:962-966. doi: 10.1016/j.applthermaleng.2007.06.033

[40] Zhang ZH, Cheung CS, Chan TL, Yao CD (2010) Experimental investigation on regulated and unregulated emissions of a diesel/methanol compound combustion engine with and without diesel oxidation catalyst, Sci Total Environ 408(4):865-872. doi: 10.1016/j.scitotenv.2009.10.060

[41] Zhang ZH, Cheung CS, Chan TL, Yao CD (2009) Emission reduction from diesel engine using fumigation methanol and diesel oxidation catalyst, Sci Total Environ 407(15):4497-4505. doi: 10.1016/j.scitotenv.2009.04.036 
[42] Wei L, Yao C, Wang Q, Pan W, Han G (2015) Combustion and emission characteristics of a turbocharged diesel engine using high premixed ratio of methanol and diesel fuel, Fuel 140:156-163. doi: 10.1016/j.fuel.2014.09.070 
Figure 1 - Schematics of the experimental apparatus.

Figure 2 - In-cylinder pressure and heat release rate at $0 \mathrm{~kW}$.

Figure 3 - In-cylinder pressure and heat release rate at $37.5 \mathrm{~kW}$.

Figure 4 - Variation of ignition delay with ethanol concentration and load power.

Figure 5 - Variation of combustion duration with ethanol concentration and load power.

Figure 6 - Variation of fuel conversion efficiency with ethanol concentration and load power.

Figure 7 - Variation of specific carbon dioxide emissions with ethanol concentration and load power.

Figure 8 - Variation of specific carbon monoxide emissions with ethanol concentration and load power.

Figure 9 - Variation of specific total hydrocarbon emissions with ethanol concentration and load power.

Figure 10 - Variation of specific nitric oxide emissions with ethanol concentration and load power.

Figure 11 - Variation of specific oxides of nitrogen emissions with ethanol concentration and load power. 


\section{LIST OF TABLE CAPTIONS}

Table 1 - Diesel engine and generator details. 


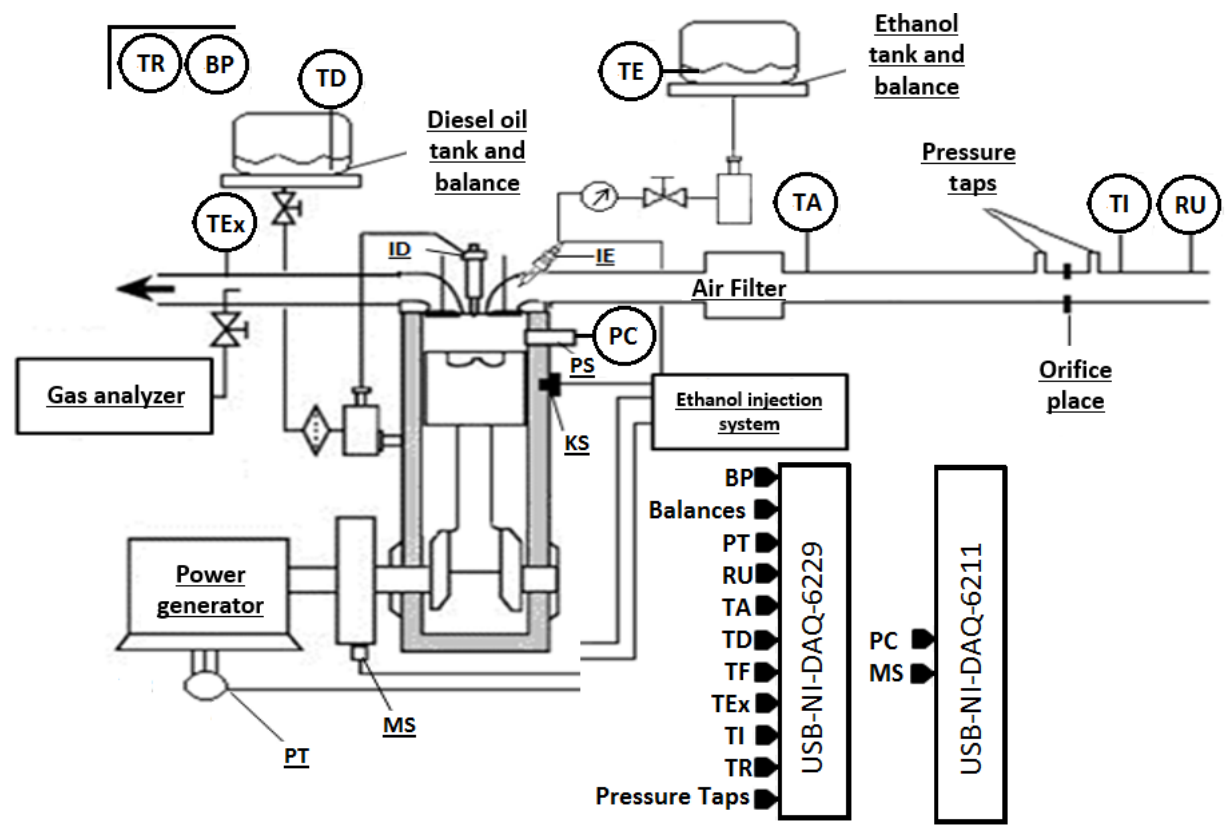

\begin{tabular}{|l|l|}
\hline BP - Barometric pressure & RU - Relative humidity \\
ID - Diesel injector & TA - Intake air temperature \\
IE - Ethanol injector & TD - Diesel oil temperature \\
KS - Knock sensor & TE - Ethanol Temperature \\
MS - Magnetic sensor & TEx - Exhaust temperature \\
PC - In-cylinder pressure & TI - Inlet air temperature \\
PT - Power transducer & TR - Room temperature \\
\hline
\end{tabular}

Fig 1 Schematics of the experimental apparatus

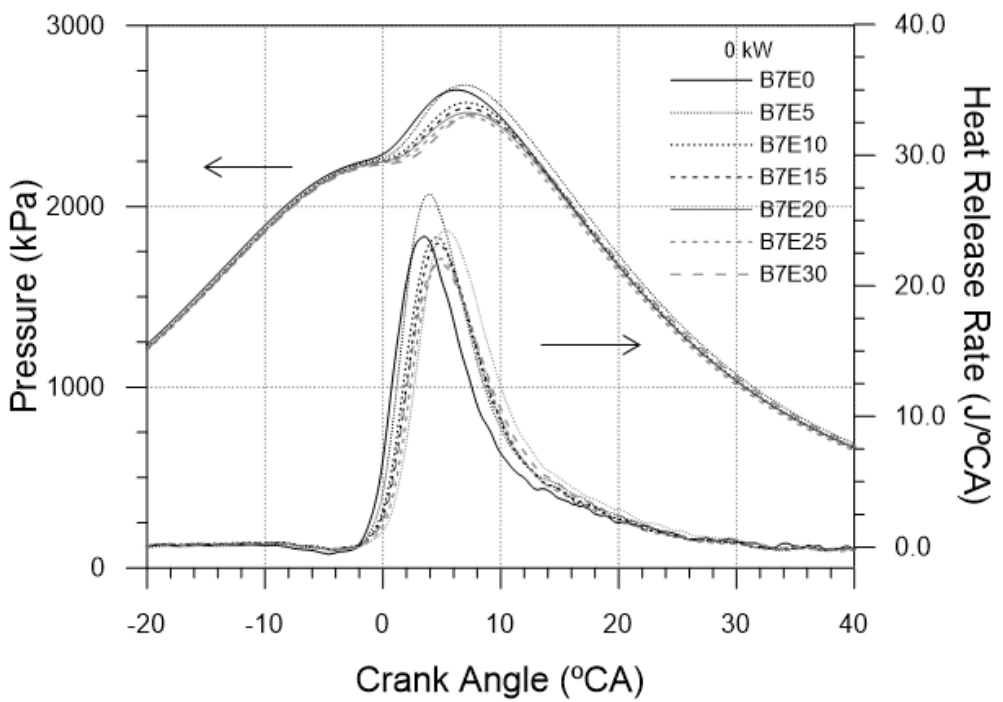

Fig 2 In-cylinder pressure and heat release rate at $0 \mathrm{~kW}$ 


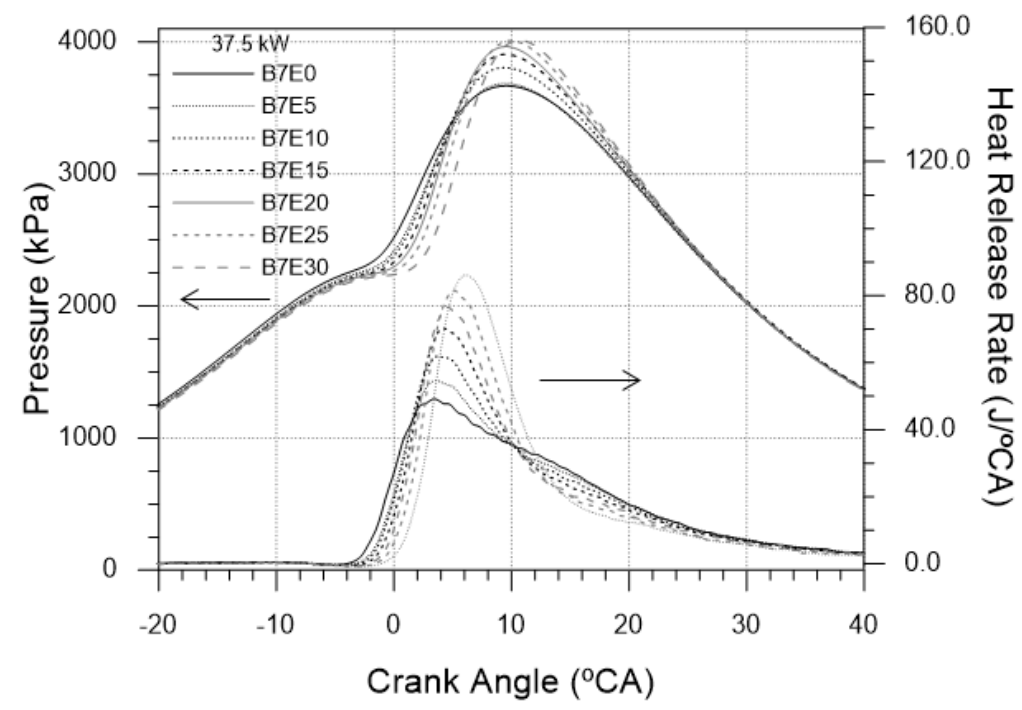

Fig 3 In-cylinder pressure and heat release rate at $37.5 \mathrm{~kW}$

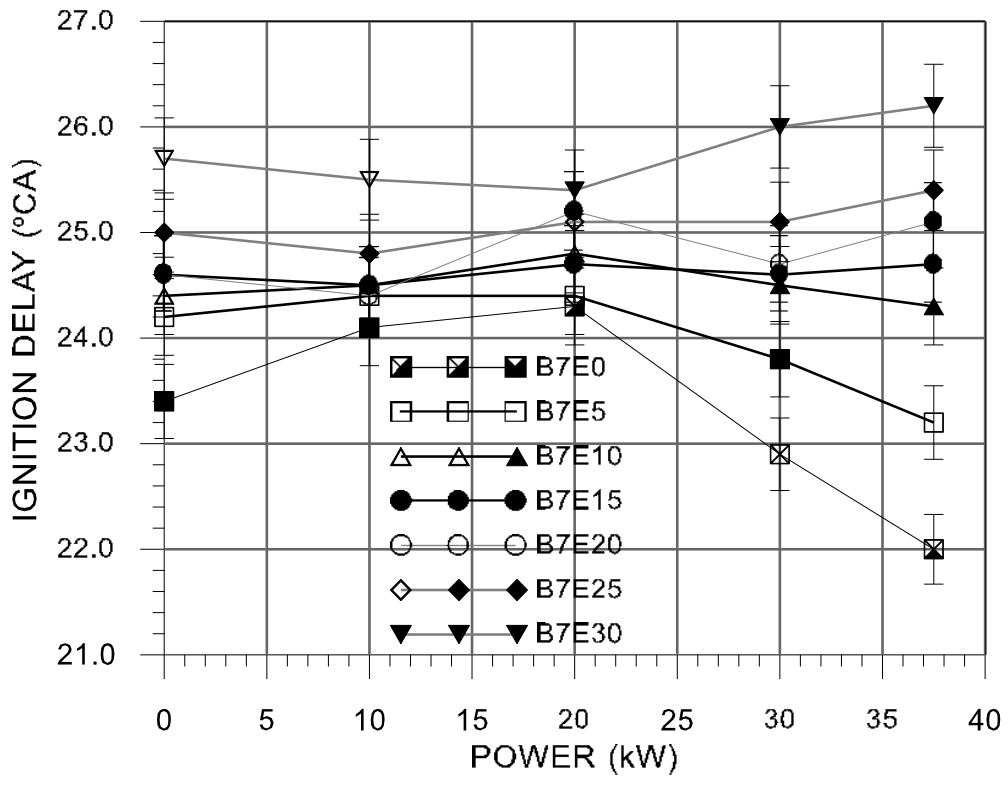

Fig 4 Variation of ignition delay with ethanol concentration and load power 


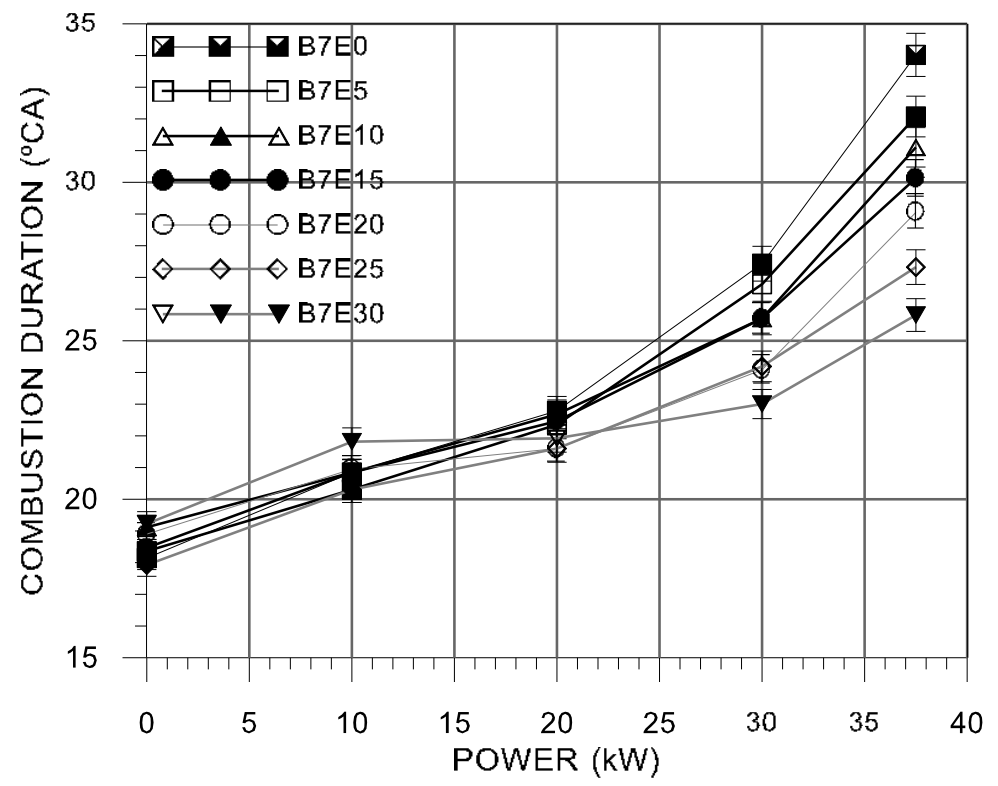

Fig 5 Variation of combustion duration with ethanol concentration and load power

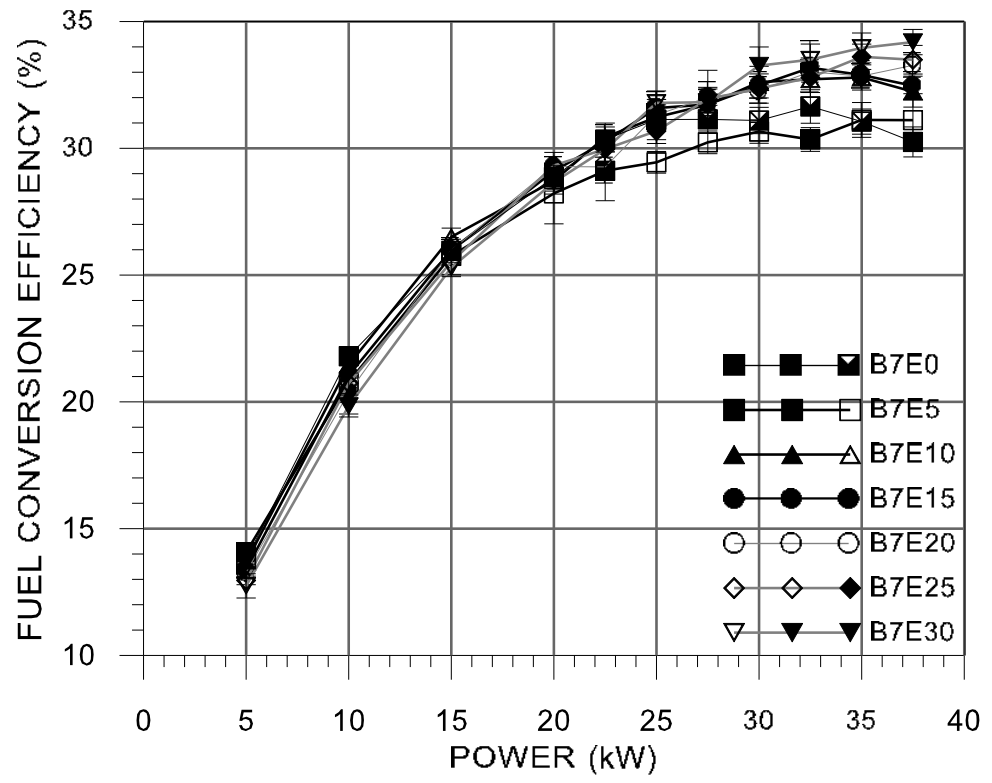

Fig 6 Variation of fuel conversion efficiency with ethanol concentration and load power 


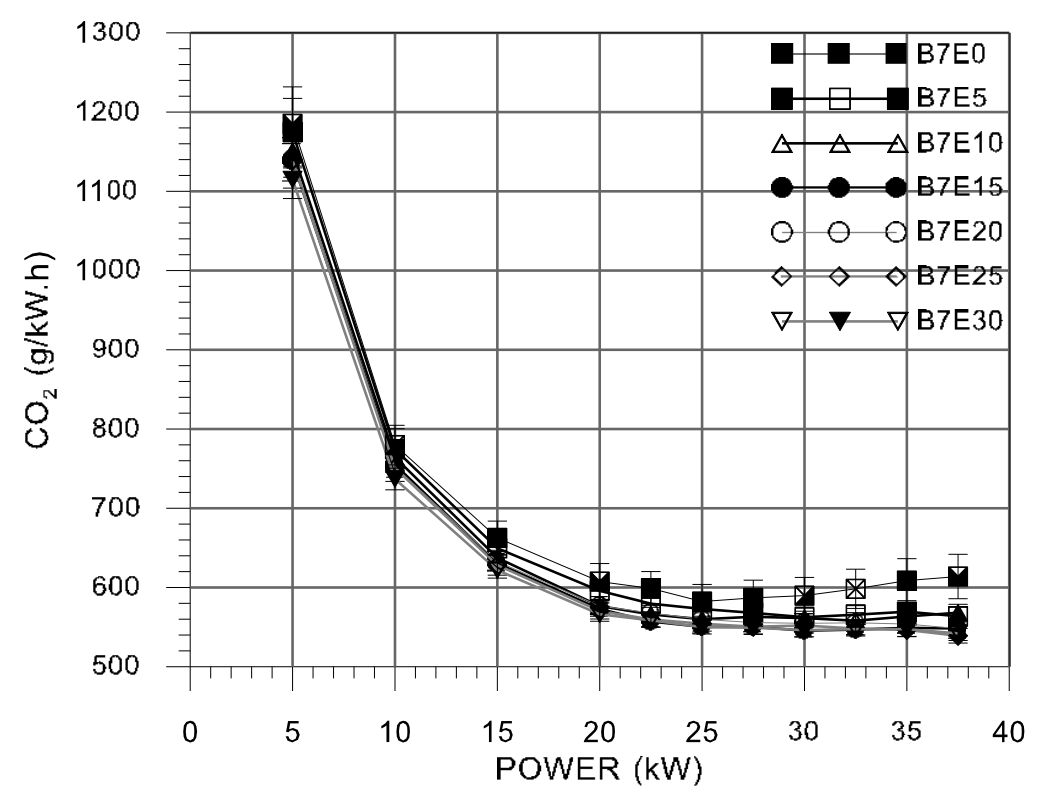

Fig 7 Variation of specific carbon dioxide emissions with ethanol concentration and load power

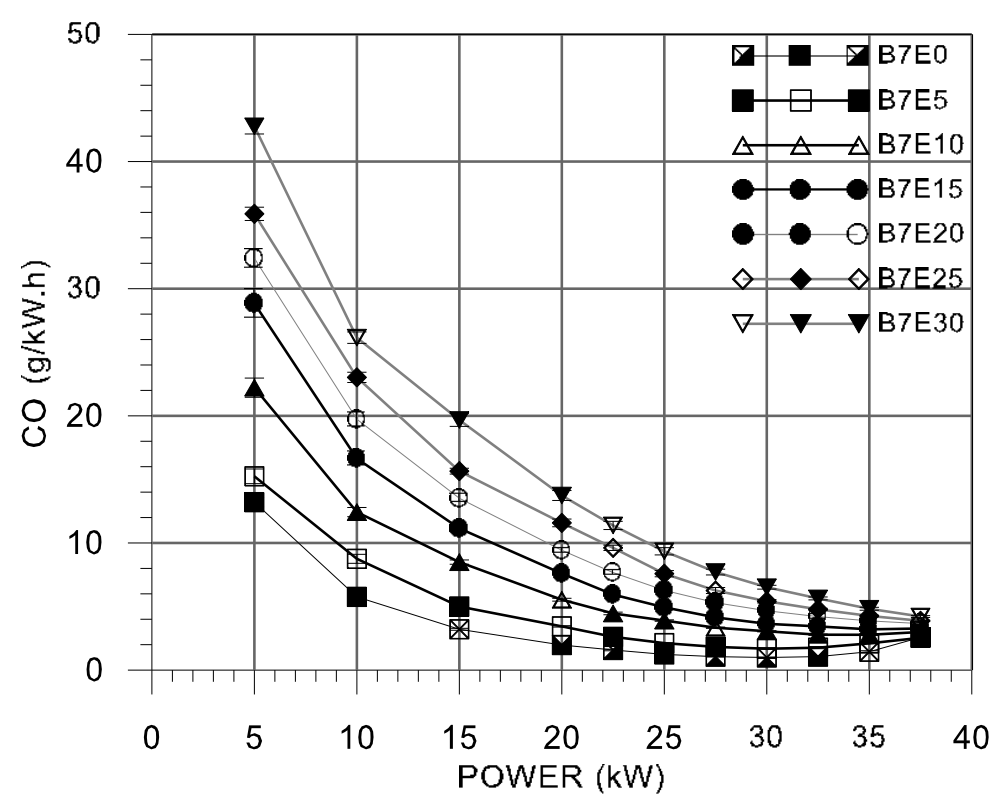

Fig 8 Variation of specific carbon monoxide emissions with ethanol concentration and load power 


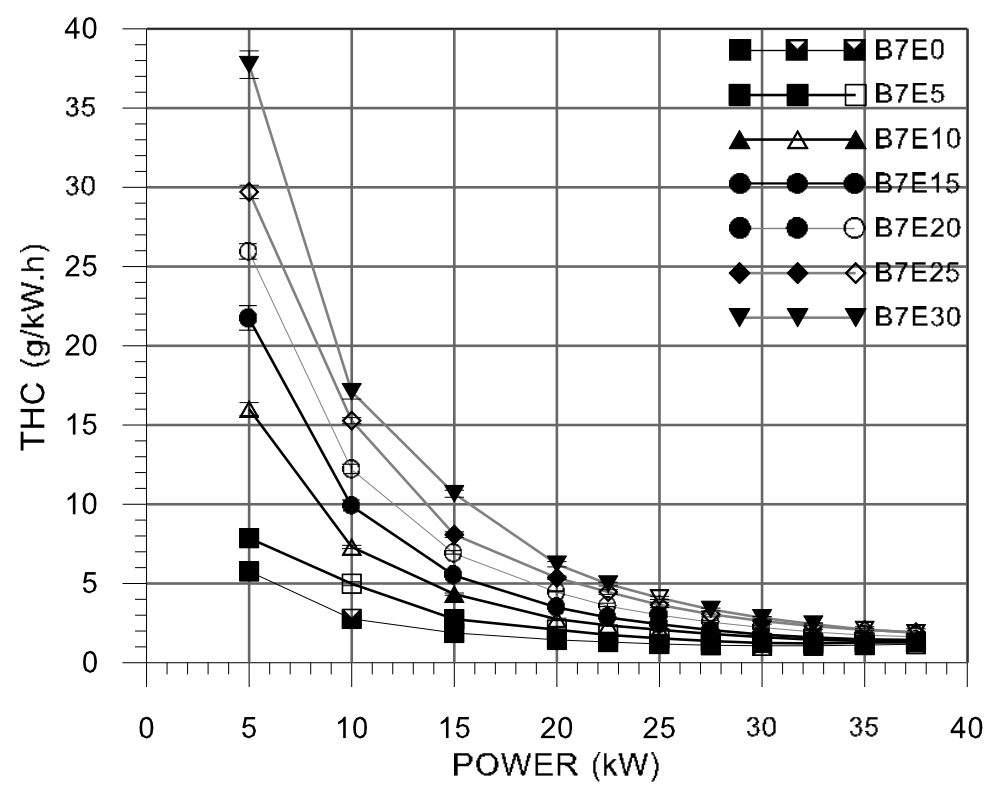

Fig 9 Variation of specific total hydrocarbon emissions with ethanol concentration and load power

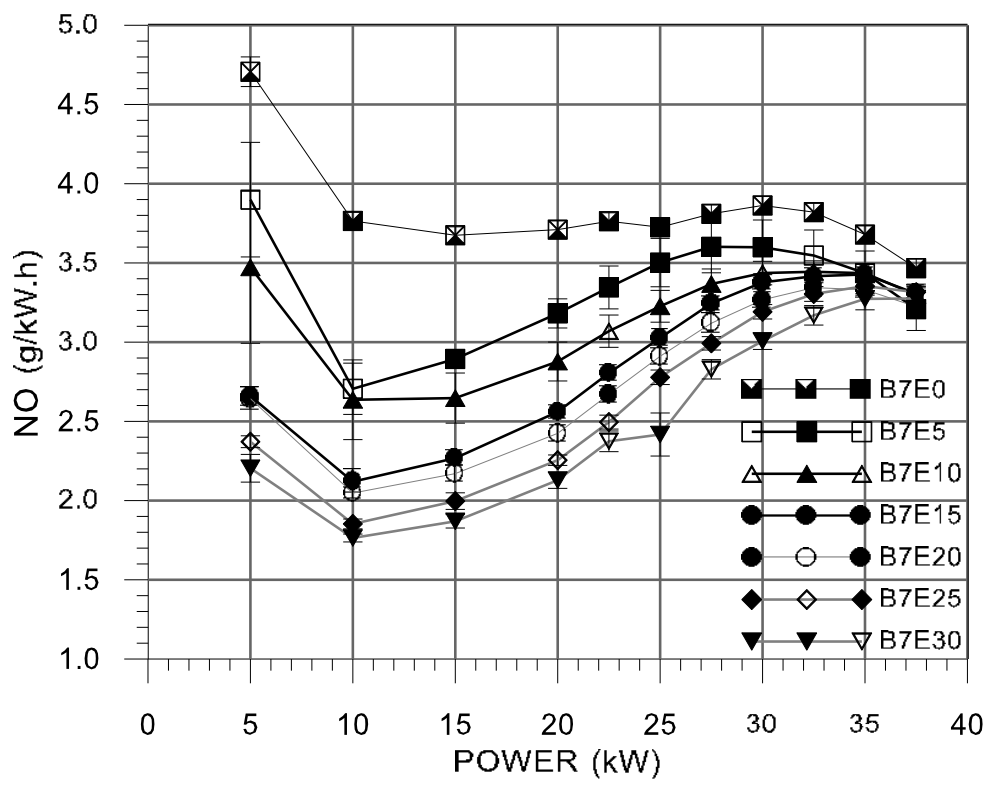

Fig 10 Variation of specific nitric oxide emissions with ethanol concentration and load power 


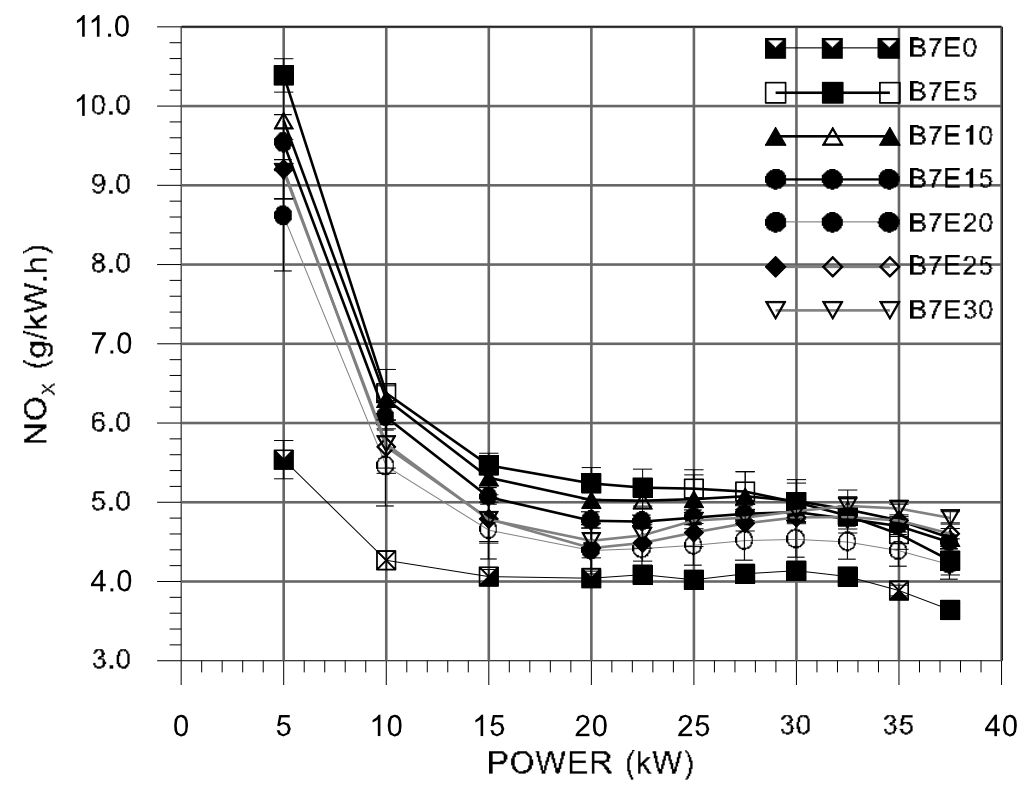

Fig 11 Variation of specific oxides of nitrogen emissions with ethanol concentration and load power 
Prof. Francisco R. Cunha

Editor-in-Chief

Journal of the Brazilian Society of Mechanical Sciences and Engineering

Dear Editor,

Thank you for the Reviewers' useful comments and suggestions on the structure of our manuscript. We have modified the manuscript accordingly, and detailed corrections are listed below point by point:

Reviewer \#1: The previous comments and indications are well reflected on the revised manuscript. Therefore, I would like to recommend this revised version as an accepted paper for the journal of BSME after the correction according to following editing comment. Comments In the manuscript, please remove the section numbers of 5 . Acknowledgement and 6 . References in pages 19 as Acknowledgement and References.

Authors' response: The number 5 was removed from the Acknowledgments section title, and the number 6 was removed from the References section title, on page 19.

Reviewer \#2: I agree with revisions done by the authors and suggest the paper be accepted for publishing.

The manuscript has been resubmitted to your journal. We look forward to your positive response.

Sincerely yours,

Prof. J. R. Sodré, Ph.D.

Corresponding author 